\title{
Thermohaline Fingerprints of the Greenland-Scotland Ridge and Fram Strait Subsidence Histories
}

Akil Hossain ${ }^{1}$, Gregor Knorr' ${ }^{1}$, Gerrit Lohmann ${ }^{1}$, Michael Stärz ${ }^{1}$, and Wilfried Jokat ${ }^{1}$

${ }^{1}$ Alfred Wegener Institute, Helmholtz-Centre for Marine and Polar Research, Bremerhaven, Germany.

Contact: Akil Hossain (akil.hossain@awi.de) 


\section{Model: COSMOS-ASO GCM}

- Earth System Model COSMOS includes atmosphere model ECHAM5, landvegetation model JSBACH and ocean model MPI-OM.

- Model setup is based on Miocene ( 23-15 Ma).

- Different GSR and FS sill depths represent different tectonic configurations during early-mid Miocene.

- Height of the Antarctic ice-sheet are reduced, Greenland ice-sheet is absent.

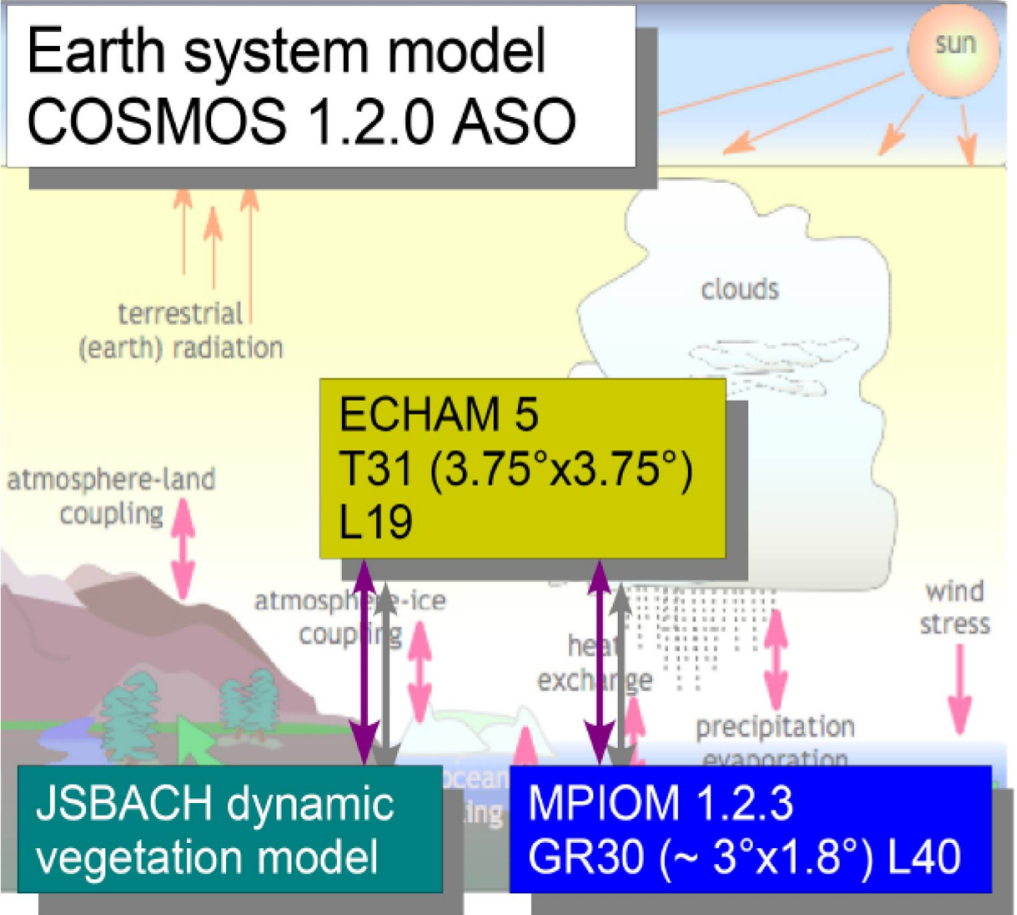

Atmosphere/ Land Surface $3.75^{\circ} \times 3.75^{\circ}$ 19 Vertical Layers
Ocean/Sea Ice $3.5^{\circ} \times 1.5^{\circ}$ higher at poles 40 uneven Layers 


\section{Model boundary conditions}

- Model setup includes orography, paleobathymetry, and ice sheet adjustments of Herold et al. (2008).

- Implements regional bathymetric reconstructions (North Atlantic/ Arctic Ocean (Ehlers and Jokat, 2013) and Weddell Sea (Huang et al., 2017)).

- Barents Sea is subaerially exposed and FS is only gateway

Global topography reconstruction (Herold et al., 2008) Ehlers and Jokat, 2013
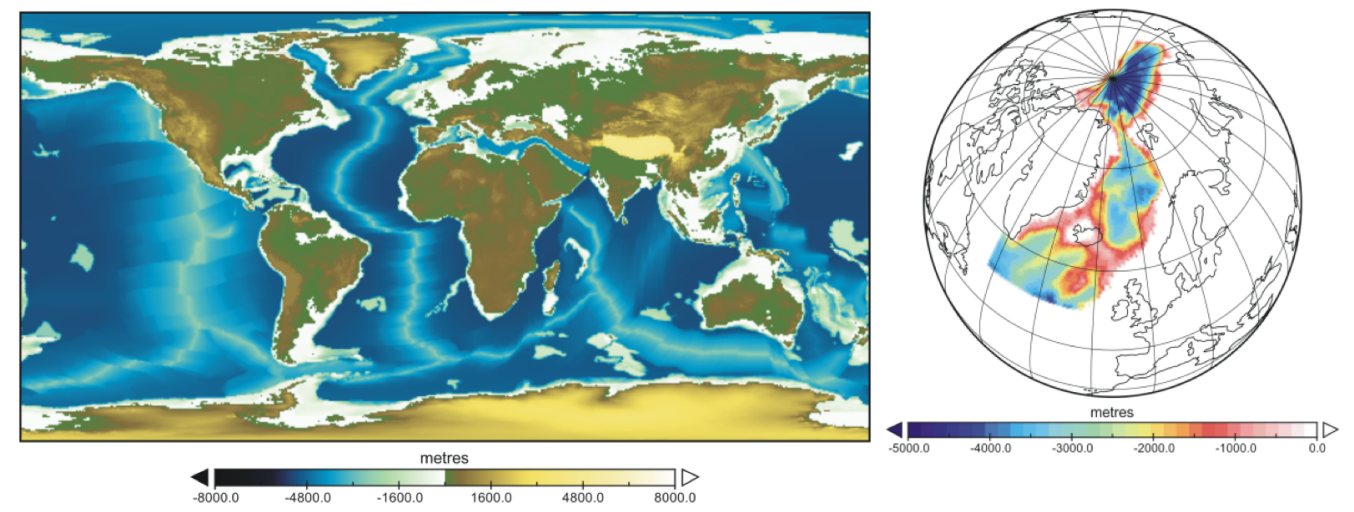

Improved bathymetry reconstructions

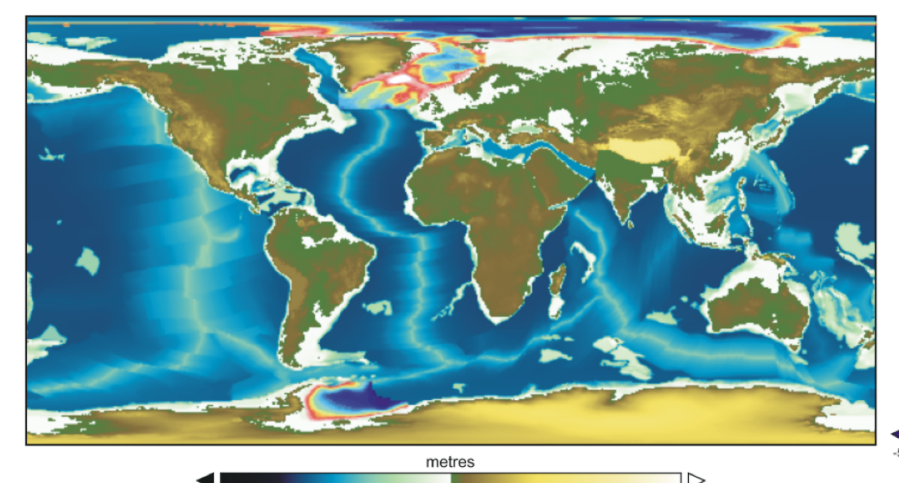

Huang et al., 2014

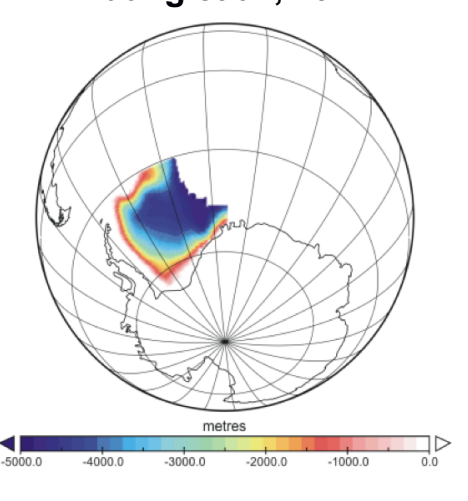
towards the Arctic. 


\section{Model experiments}

Table 1: List of sensitivity experiments

\begin{tabular}{|l|c|c|c|c|}
\hline Model Exp. & $\begin{array}{c}\text { max. Fram depth } \\
(\mathbf{m})\end{array}$ & $\begin{array}{c}\text { max. GSR } \\
\text { depth }(\mathbf{m})\end{array}$ & $\begin{array}{c}\text { Atmos. } \mathrm{CO}_{2} \\
(\mathbf{p p m})\end{array}$ & $\begin{array}{c}\text { Length of } \\
\text { simulation }(\mathbf{k y r s})\end{array}$ \\
\hline MIO_450 & $\sim 2,500 \mathrm{~m}$ & $960 \mathrm{~m}$ & 450 & 3.3 \\
\hline MIO_FS50 & $50 \mathrm{~m}$ & $960 \mathrm{~m}$ & 450 & 2.0 \\
\hline MIO_GSR40 & $\sim 2,500 \mathrm{~m}$ & $40 \mathrm{~m}$ & 450 & 2.0 \\
\hline MIO_FS50_GSR40 & $50 \mathrm{~m}$ & $40 \mathrm{~m}$ & 450 & 2.0 \\
\hline
\end{tabular}

Table 2: List of scenarios

\begin{tabular}{|c|c|c|c|}
\hline Title & Anomaly of experiments & $\begin{array}{l}\text { GSR depth change } \\
(\mathrm{m})\end{array}$ & $\begin{array}{l}\text { FS depth change } \\
(\mathrm{m})\end{array}$ \\
\hline$\Delta \mathbf{G S R} \mathbf{F S}_{\text {shallow }}$ & MIO_FS50 - MIO_FS50_GSR40 & $\sim 960-40$ & 50 \\
\hline$\Delta \mathbf{G S R}$ FS $_{\text {deep }}$ & MIO_450 - MIO_GSR40 & $\sim 960-40$ & $\sim 2500$ \\
\hline
\end{tabular}




\section{Singular effect of GSR deepening for a shallow FS}
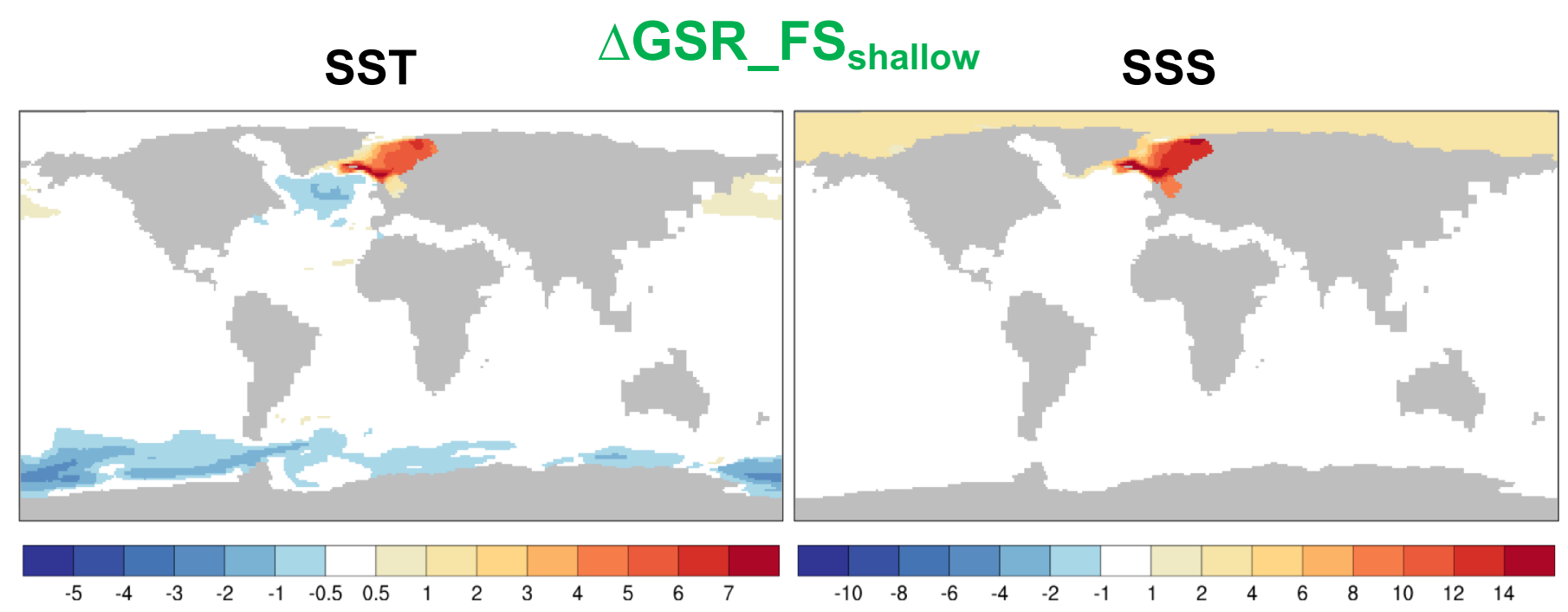

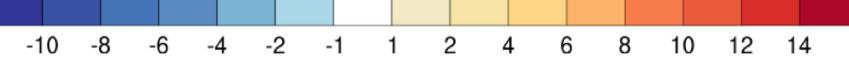

Warming and a salinity increase in the Nordic Seas/ Arctic Ocean.

zonal temperature formation takes place at cooler temperatures.

- The deep overflow of dense, cold water results from newly established NADW formation sites north of Iceland.

- Convection sites shift to the north off Iceland. NADW

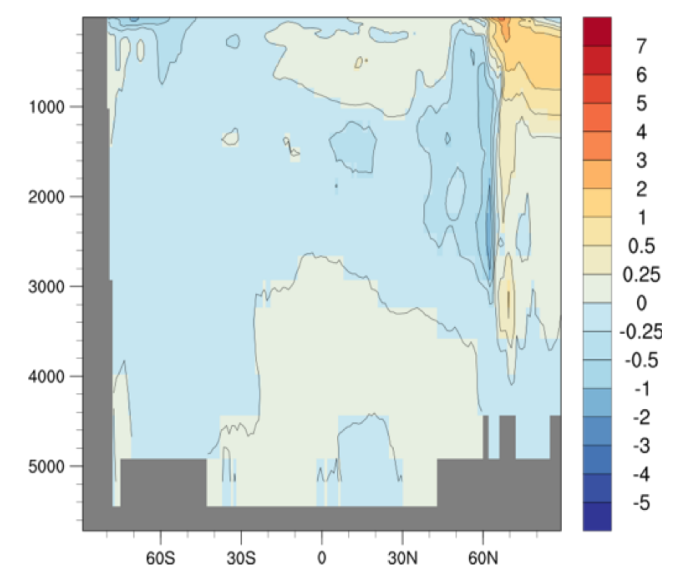

FеLMHOLTz I ASSOCIATION 


\section{Singular effect of FS deepening for a deep GSR}

zonal temperature
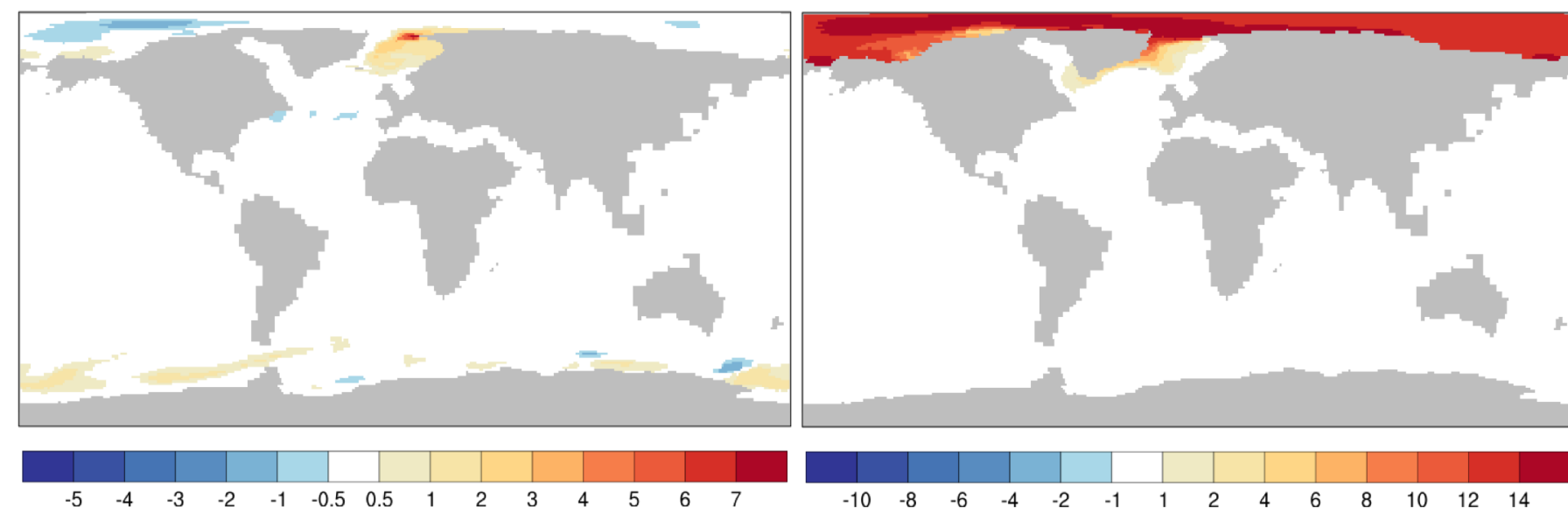

- Strong salinity increase in the Arctic increases the density of NADW by entrainment. This enhances the contribution of NADW to the abyssal ocean and at the expense of the colder southern source water component.

- These relative changes largely counteract each other and cause a negligible warming in the Southern Ocean.

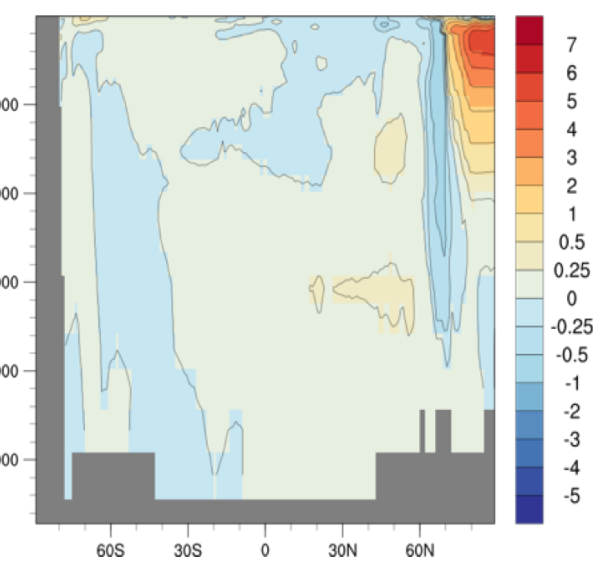

\section{zonal salinity}

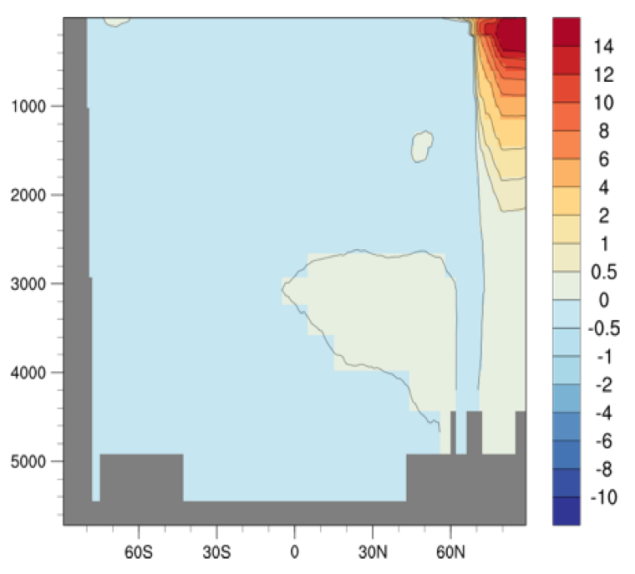




\section{Geological constraints and Outlook}

$>$ The time when GSR deepening initiated ( $36 \mathrm{Ma})$, the FS was shallow.

(Jokat at al., 2016)

$>$ Initial oceanic crust within the FS formed between 24 to 21 Ma. (Jokat et al., 2016)

$>$ GSR sill is below sea level (below $\sim 300 \mathrm{~m}$ ) between $\sim 20-24 \mathrm{Ma}$. (Stärz et al., 2017)

$>$ FS subsidence for a deep GSR is likely at time period younger than $18 \mathrm{Ma}$.

(Jokat et al., 2008; Ehlers and Jokat, 2013; Stärz et al., 2017)

Based on geological evidence and tectonic constraints:

Phase 1: GSR sill subsidence towards a deep gateway configuration for a shallow FS sill depth at $\sim 20 \pm 3 \mathrm{Ma}$ (Jokat at al., 2016)

Phase 2: the opening of FS initiated when GSR is already deeper than $\sim 300$ m between $\sim 20-24$ Ma. (Stärz et al., 2017) 


\section{THANK YOU FOR YOUR ATTENTION!!!}




\section{References}

Ehlers, B. M., \& Jokat, W. (2013). Paleo-bathymetry of the northern North Atlantic and consequences for the opening of the Fram Strait. Marine Geophysical Research, 34(1), 2543. https://doi.org/10.1007/s11001-013-9165-9

Herold, N., Seton, M., Müller, R. D., You, Y., \& Huber, M. (2008). Middle Miocene tectonic boundary conditions for use in climate models. Geochemistry, Geophysics, Geosystems, 9(10). https://doi.org/10.1029/2008GC002046

Huang, X., Stärz, M., Gohl, K., Knorr, G., \& Lohmann, G. (2017). Impact of Weddell Sea shelf progradation on Antarctic bottom water formation during the Miocene. Paleoceanography, 32(3), 304-317. https://doi.org/10.1002/2016PA002987

Jokat, W., Lehmann, P., Damaske, D., \& Nelson, J. B. (2016). Magnetic signature of North-East Greenland, the Morris Jesup Rise, the Yermak Plateau, the central Fram Strait: constraints for the rift/drift history between Greenland and Svalbard since the Eocene. Tectonophysics, 691, 98-109. https://doi.org/10.1016/j.tecto.2015.12.002

Jokat, W., Geissler, W., \& Voss, M. (2008). Basement structure of the north-western Yermak Plateau. Geophysical research letters, 35(5). https://doi.org/10.1029/2007GL032892

Stärz, M., Jokat, W., Knorr, G., \& Lohmann, G. (2017). Threshold in North Atlantic-Arctic Ocean circulation controlled by the subsidence of the Greenland-Scotland Ridge. Nature communications, 8,15681 . https://doi.org/10.1038/ncomms15681 